\title{
Recent advances in the use of Glycoprotein (GP) Ilb/llla receptors inhibitors
}

\section{Roshan Raui, Man Bahadur KC, Deewakar sharma, Sujeeb Rajbhandari, Sajan G. Baidhya}

Glycoprotein IIb/Illa receptors are the most common receptor subtypes on the platelet surface. During vessel injury, the sub-endothelial layer is exposed so that platelets adhere to sub-endothelial collagen via la/lla receptor and to von Willebrand factor via glycoprotein Ib receptor. Adherent platelets are activated by ADP, 5-HT, TXA2 etc which result in the conformational change of platelets, thereby activating nearly $80,000 \mathrm{GP}$ Ilb/Illa receptors on platelet surface. These activated receptors bind fibrinogen to fascilate the formation of a platelet plug. ${ }^{1,2}$

Currently, there are three GP Ilb/llla inhibitors available for clinical use, Abciximab, Ebtifibatide and Tirofabin. This review article will highlight on the recent trends for the use of GP Ilb/llla inhibitors in different clinical settings. First of all, the use of GP Ilb/llla inhibitors is divided into two large groups, during $\mathrm{PCl}$ and during. Conservative management. During $P C T$, its use is again categorized into three subgroups: PCl for stable CAD, in the setting of Non-ST segment elevation acute coronary syndrome(NSTE-ACS, that is, unstable angina and Non-ST elevation MI) and, ST segment elevation MI (STEMI). Similarly, during conservative management, its use is discussed in two subgroups: in the setting of NSTEACS and in STEMI. This article will also discuss on specific situations like diabetics patients undergoing $\mathrm{PCl}$ and high risk NSTE-ACS.

\section{GP IIb/IIla inhibitors during $\mathrm{PCI}$}

\section{A. Role during $\mathrm{PCI}$ in Stable CAD}

The role of GP Ilb/llla receptors inhibitors during $\mathrm{PCl}$ was first studied in three large randomized trials total enrolling more than 7,000 patients: EPIC ${ }^{3}$, EPILOG ${ }^{4}$ and EPISTENT ${ }^{5}$ trials. EPIC trial ${ }^{3}$ ( Evaluation of $7 \mathrm{E}-3$ for the Prevention of Ischemic Complications) was a prospective, randomized double blinded trial including 2,099 patients with severe unstable angina, evolving $\mathrm{Ml}$ and high risk coronary morphology in 56 centers and found that there was $35 \%$ reduction in the composite end point of death, MI and TVR in Abciximab bolus+ 


\section{- NEPALESE HEART JOURNAL •}

IV infusion ( $P=0.008)$ and $10 \%$ reduction in Abciximab bolus + placebo infusion $(P=0.43)$, There was a $20 \%$ reduction in composite end point in 6 month follow up $(P=0.001)$ with doubling of major bleeds. The EPILOG trial ${ }^{4}$ (Evaluation in PTCA to Improve Long term Outcome with abciximab GPIIb/IIla blockade) randomized 2,792 patients undergoing urgent or elective $\mathrm{PCl}$, At 30 days follow up, it was found that there were $11.7 \%, 5.4 \%$ and $5.2 \%$ incidences of composite end point (death, MI and TVR) in placebo, abciximab+ low dose heparin and Abciximab+ standard dose heparin, respectively. Similarly the EPISTENT trial ${ }^{5}$ (Evaluation of Platelet Ilb/ IIla Inhibitor for stenting) randomized 2,399 patients undergoing elective or urgent $\mathrm{PCl}$ and found that there was $5.5 \%$ reduction of death or $\mathrm{MI}$ at 30 days.

This benefit sustained at 6 months follow up too, with $5.8 \%$ reduction of death or Mi in the favor of Abciximab. In pooled analysis of above 3 trials, percentage risk reduction in primary end point at 30 days was $57 \%, 58 \%$ and $44 \%$ in low, moderate and high risk patients respectively. There was $22 \%$ relative reduction in mortality with abciximab at 3 years. ${ }^{33}$ Although the treatment effect was present in both low risk and high risk group, patients with complex coronary lesions achieved greater benefit, one year reduction of composite end point of death and $\mathrm{MI}$ by $50 \%$ in the complex lesion group. ${ }^{34}$ However, the above trials enrolled the mixed population of stable and unstable CAD. So, its role during elective $\mathrm{PCI}$ for stable CAD cannot be concluded fully on the basis of above trials. The ISAR-REACT trial (Intra- coronary Stenting and Anti thrombotic Regimen-Rapid Early Action for Coronary Treatment) ${ }^{6}$ highlight this issue. This trial enrolled more than 2,000 patients with stable CAD to receive either Abciximab or placebo during low-intermediate risk $\mathrm{PCl}$. All patients were pretreated with a $600 \mathrm{mg}$ dose of clopidogrel at least 2 hours before the procedure. Administration of Abciximab failed to provide any additional clinical benefit with respect to the composite end point ol death, MI and TVR. Even at the follow up of 1 year, no trends of clinical benefit was observed. Thus, at present, as per the data available from the ISAR-REACT trial, stable CAD with low to intermediate risk PCI can be managed adequately with loading high dose of clopidogrel. Whether this benefit of pre-loading high dose clopidogrel can also be seen in high risk ACS, is being addressed in ISAR-REACT-2 and BRAVE-3 trials. The 2005 ESC guidelines recommend the use of GP IIb/IIla during PCI in stable CAD if there is complex angiographic lesions, threatened / actual vessel closure, visible thrombus and no/slow reflow phenomenon, ${ }^{35}$ 
The result of $\mathrm{PCl}$ in diabetic patients is not as good as non-diabetic patients. This is perhaps due to enhanced platelet activation, aggregability and greater expression of GP Ilb/IIla receptors. So, there might be hypothesis that diabetic patients need to be managed more aggressively using GP IIb/llla inhibitors during $\mathrm{PCl}$. The retrospective analysis of diabetic subgroups in EPISTENT study showed that there is prognostic benefit of Abciximab in diabetic groups. ${ }^{36}$ But as stated earlier this study had mixed population of stable and unstable CAD and the subgroup analysis was retrospective not prospective. This issue has been highlighted in ISAR- SWEET trial. ${ }^{7}$ ISAR-SWEET (is abciximab Superior Way to Eliminate Thrombotic risk in diubetes) was a prospective trial enrolling diabetic patients undergoing elective $\mathrm{PCl}$ with pre-treatment by $600 \mathrm{mg}$ clopidogrel. The result showed that Abciximab did not provide extra benefit in terms of death and MI. Thus, whether Abciximab should be routinely used in all diabetic patients undergoing elective $\mathrm{PCl}$ is not yet proved.

In comparision to Abciximab, the benefits were less marked with the use of small molecules GP IIb/IIla inhibitors (Ebtifibatide and tirofabin) as observed in IMPACT-II trial $^{9}$ with Ebtifibatide and RESTORE trial ${ }^{12}$ with Tirofiban.

\section{B. Role during PCT for NSTE-ACS (Unstable angina and NSTEMI)}

Although benefit of GP Ilb/Illa inhibitors is seen across all groups, this benefit is more prominent in ACS patients. There are several trials showing the usefulness of GP IIb/IIla inhibitors in patients with stable angina or NSTE-ACS. Among three GP Ilb/llla inhibitors, Abciximab has been extensively studied as in EPIC, EPILOG, EPISTENT and CAPTURE trial $^{8}$. The role of ebtifibatide has been studied in IMPACT-II and ESPIRIT ${ }^{10,11}$ trials and that of Tirofiban in RESTORE ${ }^{12}$ and TARGET trials, ${ }^{13}$ There is prominent role of Abciximab during PCI in ACS patients as shown in EPIC, EPILOG and EPISTENT trial. But it should be noted that these trial comprised the mixed population of stable and unstable CAD, The CAPTURE trial ${ }^{8}$ (Chimeric 7E3 AntiPlatelet Therapy in Unstable angina refractory to standard treatment) has been especially designed to observe the usefulness of Abciximab during $\mathrm{PCl}$ in unstable angina. The 30 day composite end point of death, MI or TVR was significantly reduced in the favour of Abciximab therapy (15.95 vs $11.3 \%, p=0.012$ ).

Whether the small molecule GP IIb/IIla was also useful during PCI in NSTE- ACS was studied in IMPACT-II ${ }^{9}$ and ESPIRIT ${ }^{10,11}$ trials for Ebtifibatide and in RESTORE ${ }^{12}$ and TARGET ${ }^{13}$ trials for Tirofiban. 
The IMPACT trial $^{9}$ (Integrilin to Manage Platelet Aggregation to prevent Coronary Thrombosis) was a double blind multi-centers trial enrolling 4,010 patients undergoing PCI which was randomized into 3 groups: placebo, $135 \mathrm{ug} / \mathrm{kg}$ bolus Ebtifibatide + low dose infusion $(0.5 \mathrm{ug} / \mathrm{kg} / \mathrm{min})$ for 20 to 24 hours and $135 \mathrm{ug} / \mathrm{kg}$ bolus Ebtifibatide + high dose infusion $(0.75 \mathrm{ug} / \mathrm{kg} / \mathrm{min}$ for 20 to 24 hours. The 30 day composite end point of death, MI, unplanned surgical or repeat $\mathrm{PCl}$ or coronary stent implantation for abrupt closure occurred in $11.4 \%, 9.2 \%(p=0.0630$ and $9.9 \%$ ( $p=0.22)$ respectively, As the benefit of Ebtifibatide was not observed in IMPACT- II trial, perhaps due to low dose, another trial with higher dose of Ebtifibatide was conducted, the ESPIRIT ${ }^{10,11}$ trial (Enhanced Suppression of platelet IIb/IIla Receptor with Integrilin Therapy). A total of 2,064 patients were enrolled with a double bolus regimen of Ebtifibatide (180ug/kg bolus followed by $2 \mathrm{ug} / \mathrm{kg} / \mathrm{min}$ infusion with a second bolus of $180 \mathrm{ug} / \mathrm{kg}$ given $10 \mathrm{~min}$ after the first bolus) compared to placebo treatment. The 48 hour primary composite end point of death, MI, urgent TVR or bailout treatment with Ebtifibatide was reduced $37 \%$ from 10.5 to $6.65(p=0.0015)$. There was a consistent treatment benefit across all components of the end point as well as across all subgroups of patients. At 30 days, the secondary composite end point of death, MI or urgent TVR was improved by $35 \%$ from 10.4 to $6.85(p=0.0034)$

The beneficial effect of Tirofiban is less robust as shown in RESTORE and TARGET trials. In RESTORE trial ${ }^{12}$ (Randomized Efficacy Study of Tirofiban for Outcomes and Restenosis), the composite end point of death, MI, urgent TVR or bailout treatment was $12.2 \%$ in placebo vs $10.3 \%$ in Tirofiban group, which was not statistically significant. Further, Tirofiban was directly compared with Abciximab in TARGET trial ${ }^{13}$ (Do Tirofiban And Reopro Give similar Efficacy). It was found that Abciximab was superior to Tirofiban in reducing composite end point of death, MI or TVR at 30 days in the subgroup of patients with ACS (6.35 vs $9.3 \%$, $p=0.002$ ). The TENACITY trial will study a higher dose of Tirofiban than in TARGET and compare it head to head with Abciximab.

In conclusion, when $\mathrm{PCl}$ is planned, Abciximab is the best tested drug, as shown in EPIC, EPILOG, EPISTENT and CAPTURE trials. In such setting, high dose Ebtifibatide is also better alternative as shown in ESPIRIT trial but the role of Tirofiban is still controversial. 


\section{Role during $\mathrm{PCl}$ in ST segment elevation $\mathrm{MI}$ (during primary $\mathrm{PCl}$ )}

Despite successful revascularization in primary $\mathrm{PCl}$, there might be sub-optimal microvascular reperfusion due to distal embolization with platelet aggregrgates which necessitate the use of potent anuplitelet agent. The role of GP IIb/llla inhibitors, especially Abciximab has been well studied in the setting of primary PCI. Abciximab has been studied in five randomized trials ${ }^{14,18}$ (RAPPORT, ISAR- 2, CADILLAC, ADMIRAL and ACE trials) total enrolling more than 3,000 patients undergoing primary $\mathrm{PCl}$. At 30 days and 6 months follow up, all the trials demonstrated beneficial effect in terms of a composite end point of death, reinfarction or TVR, however when only death or death + reinfarction was evaluated, none of the tial showed the clear cut benefit.Thus, Abciximab was especially benefit in terms of TVR. The pooled analysis of the five trials revealed that Abciximab was not only better in terms of TVR but also re-infarction, however not in mortility, 10.5/4.5 $(P<0.05)$, 8.5/4.0 $(p<0.05)$ and 4/3.5 (not significant) for placebo Abciximab respectively, The 2005 ESC guideline recommend the use of Abciximab during primary $\mathrm{PCl}$ as class lla indication. The role of other small molecule GPIIb/Illa is well investigated in the setting of primary PCI.

\section{Role during conservative management}

\section{A, In Non-ST segment elevation acute coronary syndrome( Unstable angina and NSTEMI)}

Clinical efficacy of GP IIb/llla inhibitors in patients with NSTE-ACS who are not routinely scheduled to undergo revascularization is less obvious. Six major randomized trials ${ }^{19-24}$ : Platelet Receptor Inhibition in ischemic Syndrome Management (PRISM). Platelet Receptor Inhibition in ischemic Syndrome Management in Patients Limited by Unstable Signs and symptoms (PRISM-PLUS), Platelet IIb/IIla Antagonism for the Reduction of acute coronary syndrome events in a Global Organization network (PARAGON-A), PARAGON-B, Platelet glycoprotein Ilb/llla in Unstable angina;Receptor Suppression Using Integrilin Therapy (PURSUIT) and the Global Utilization of Strategies To Open occluded coronary arteries (GUSTO-IV ACS) enrolling more than 30,000 patients have addressed this issue. The $\mathrm{PCl}$ was not scheduled and even discouraged in these trials so that the $\mathrm{PCl}$ rates are low ranging from $1-6 \%$ to $30.5 \%$. Ebtfibatide showed benefit in terms of death and $\mathrm{Ml}$ in PERSUIT trial and Tirofiban in terms of death, MI or TVR in PRISM and PRISM-PLUS trials. But Abciximab failed to show benefit in GUSTO-4 ACS trial and similarly Lamifabin in PARAGON and PARAGON: B trials. Ebtifibatide was studied in PERSUIT trial enrolling 
10,948 patients, the biggest trial among the six trials, showed the composite end point of death and $\mathrm{MI}$ of $15.7 \%$ in placebo arm vs $14.2 \%$ in Ebtifibatide arm $(p<0.05)$. In PRISM trial which enrolled 3,332 unstable angina patients, had incidence of death, MI or TVR of $5.6 \%$ in placebo arm compared to $3.8 \%$ in Tirofiban arm $(p<0.05)$. PRISM-PLUS trial showed the similar result. However, in GUSTO IV-ACS trial, the composite end point of death and $\mathrm{MI}$ was $8 \%, 8.2 \%$ and $9.1 \%$ respectively in placebo, Abciximab for $24 \mathrm{hr}$ and Abciximab for $48 \mathrm{hr}$ respectively which was not statistically significant.

Thus, as per the data available from PERSUIT trial, Ebtifibatide is recommended in NSTEACS when $\mathrm{PCl}$ is not planned, Similarly, Tirofiban is also recommended in this setting as per the data available from PRISM and PRISM-PLUS trials, But Abciximab, which is the best tested drug during $\mathrm{PCl}$, is not recommended when $\mathrm{PCl}$ is not planned on the basis of data available from GUSTO-V ACS trial.

Although, the benefit of GPIIb/IIla was observed in all NSTE-ACS, this benefit was markedly enhanced when viewed according to risk stratification (TIMI risk score, tropinin level, ST segment changes, diabetes etc). Use of GP IIb/Illa inhibitors was associated with $15 \%$ relative risk reduction in the 30 days end point in troponin positive patients $(10.3 \% \mathrm{vs}$ $12 \%) .{ }^{21}$ In comparision, in patients with negative tropinins, no risk reduction was seen $(7 \%$ vs $6.2 \%)$. This differential treatment with respect to tropinin level was significant $(P=0.045)$. Meta analysis of diabetic patients in these six trials revealed a $26 \%$ mortality reduction with the use of these agents as compared to placebo. ${ }^{37}$ Thus, use of GP IIb/IIla should be a standard practice in high risk NSTE-ACS.

\section{B. In ST segment elevation MI:}

The role of GP IIb/Illa is not obvious in the patients undergoing thrombolysis. Although the combination therapy of thrombolysis and GP Ilb/llla was encouraging in several pilot studies, the initial trials with the combination of streptokinase and abCiximab or ebtifibatide was discontinued due to excessive bleeding complications. Two 6 phase trials ${ }^{25-30}$ : TIMI 14, SPEED, INTRO-AMI, INTREGITI, TIMI 20, ENTIRE TIMI 23, FASTER TIMI 24 tested the optimal combination of reduced dose(50-75\%) of thrombolytic agents(Tpa,r-pa,TNK) with GP Ilb/Illa inhibitors(Abciximab, Ebtifibatide, Tirofiban) as compared to full dose thrombolytic therapy. The TIMI perfusion grade. The blush score and ST segment resolution was significantly enhanced in the favor of combination therapy, however the clinical impact 
of thies benefit was not tested in the above trials, The two large trials, GUSTO $V^{31}$ and ASSENT- 3$)^{32}$ trial tested the clinical impact of combination therapy. In GUSTO $\vee$ trial, although there was significant reduction in the rate of non fatal ischemic events, these benefits was not translated into mortality benefit. Similarly, in ASSENT-3 trial, no mortality benefit was seen. Thus, combination therapy, although provides reduction in secondary end points, is not associated with mortality benefit over standard thrombolytic therapy, 50 at present, the combination therapy cannot be used as routine management in our clinical settings.

\section{Conclusion:}

GP Ilb/llla inhibitors should not be routinely used during elective low-intermediate risk PCT, as per data available from ISAR-REACT trial, Its use during elective low risk $\mathrm{PCl}$ for diabetic patients is controversial as Abciximab failed to show extra benefit in ISAR-SWEET trial, especially designed for diabetic patients. During PCI for NSTEACS, abciximab is the best tested drug (EPIC, EPILOG, EPISTENT, CAPTURE trials), The role of Ebtifibatide in this setting is evident from ESPIRIT trial. However, current data does not support the use of Tirofiban (TARGET, RESTORE trials) in this clinical setting, During primary $\mathrm{PCl}$, the role of Abciximab is supported by RAPPORT, ISAR-2, CADILLAC, ADMIRAL and ACE trials, but of note, neither of the trials showed mortality benefits, Ebtifibatide and Tirofiban are less investigated during primary $\mathrm{PCl}$, When $\mathrm{PCl}$ is not planned, both Ebtifibatide or Tirofiban can be used (PERSUIT, PRISM, PRISMPLUS irials), But data from GUSTO IV ACS does not support Abciximab, when PCT is not planned. During thrombolysis, although few trials showed that GP Ilb/llla is beneficial in terms of reducing secondary end points, there was no mortility benefit, and so, until further data can be obtained the use of GP Ilb/llla during. thrombolysis should be avoided. 


\section{References}

1. TOPOL EJ, Byzova TV, Plow EF, Platelet GP Ilb/llla blockers, Lancet 1999; 353: 227-31,

2. Vorchheimer DA, Badimon JJ, Fuster V. Platelet glycoprotein IIb/IIla receptor antagonists in cardiovascular disease, Journal of the American Medical Association 1999; 281: 1407-14

3. The EPIC investigators. Use of a monoclonal antibody directed against the platelet glycoprotein Ilb/Illa receptor in high risk coronary angioplasty. N Engl J Med 1994; 330:956-61,

4. The EPILOG Investigators Platelet glycoprotein IIb/llla receptor blockade and lowdose heparin during percutaneous coronary revascularization:,N Engl J Med 1997; $336 ; 1689-96$,

5. Randomised placebo-contralled and balloon-angioplasty-controlled trial to assess safety of coronary stenting with use of platelet glycoprotein Ilb/Illa blockade. The EPISTENT Investigators, Evaluation of Platelet IIb/IIla Inhibitor for Stenting, Lancet 1998;352: 87-92.

6. Kastrati A. MehilliJ, Schuhlen H, Dirschinger J, Dotzer F, ten Berg JM, et al. Intracoronary stenting and antithrombotic regimen Rapid Early Action for Coronary treatment Study Investigators. A clinical trial of Abciximab in elective percutaneous coronary intervention after pretreatment with clopidogrel, N Engl J Med 2004; 350: 232-238

7. MehilliJ, Kastrati A, Schuhlen H, Dibra A, Dotzer F, von Beckerath N, et al. Intracoronary stenting and Antithrombotic Regimen: Is Abciximab a Superior Way to Eliminate Elivated Thrombotic Risk in Diabeties (ISAR-SWEETS) study investigators. Randomized clinical trial of Abeiximab in diabetic patients undergoing elective percutaneous coronary interventions after treatment with a high loading dose of clopidogrel. Circulation 2004: 110; 3627-3635 
8. CAPTURE Investigators. Randomised placebos controlled trial of abciximab before and during coronary intervention in refractory unstable angina the CAPTURE Study, Lancet 1997; 349; 1429 -35.

9. Randomised placebo-controlled trial of effect of eptifibatide on complications of percutaneous coronary intervention: IMPACT-IL, lategrilin to Minimise Platelet Aggregation and Coronary Thrombosis-II, Lancet 1997; 349; 1422- 8,

10. Novel dosing regimen of epufibatide in planned coronary stent implantation (ESPRIT); a randomized, placebo-controlled trial, Lancet 2000;356:2037- 44,

11. Design and methodology of the ESPRIT trial: evaluating a novel dosing regimen eptifibaride In precancerous coronary intervention, Am Heart J 2000; 140:834 9,

12. Ande.son HV, Kirkecide RL, Krishnaswarmi A, et al. Cyclic flow Effects of platelet glycoprotein Ilb/llla blockade with tirofiban on adverse cardiac events in patients with unstable angina or acute myocardial infarction undergoing coronary angioplasty: the RESTORE Investigators, Randomized Efficacy tudy of Tirofiban for Outcomes and Restenosis, Circulation 1997:96: 1445-53,

13. Topol EJ, Moliterno DJ, Herrmann HC, Powers ER, Grines CL, Cohen DJ, et al. TARGET Investigators, Do Tirofiban and Reo Oro Give Similar Efficacy Trial. Comparision of the two platelet glycoprotein Ilb/ Illa inhibitors, tirofiban and abciximab, for the prevention of Ischemic events with percutaneous revascularization. N Engl J Med 2001; 344; 1888-1894

14. Brener SJ, Barr LA, Burchenal JE, etal, for the ReoPro and Primary PTCA Organization and Randomized Trial (RAPPORT) Investigators. Randomized, placebo-controlled trial of platelet glycoprotein IIb/IIla blockade with primary angioplasty for acute myocardial infarction, Circulation 1998;98; 734-41, 
15. Neumann FJ, Kastrati A, Schmitt C, et al. Effect of glycoprotein Ilb/IIla receptor blockade with abciximab on clinical and angiographic restenosis rate affer the placement of coronary stents following acute myocardial infarction. J Am Coll Cardiol 2000;35;915-21,

16. Montalescot G, Barragan P, Wittenberg O, et al, for the Abciximab before Direct Angioplasty and Stenting in Myocardial Infarction Regarding Acute and Long-Term Follow-up (ADMIRAL) Investigators, Platelet glycoprotein Ib/lla inhibition with coronary stenting for acute myocardial infarction, N Engl Med 2001;344; 1895-903.

17. Stone GW, Grines CL, Cox DA, et al, for the Controlled Abciximab and Device Investigation to Lower Late Angioplasty Complications (CADILLAC) Investigators. Comparison of angioplasty with stenting, with or without abciximab, in-acute myocardial infarction, N Engl J Med 2002;346:957-66,

18. Antoniucce' D. Rodriguez A, Hempel A, etal, A randomized trial comparing primary infarct artery stenting with or without abciximab in acute myocardial infarction, J Am Coll Cardiol 2003;42: 1879-85,

19. Inhibition of platelet glycoprotein IIb/IIla with eptifibatide in patients with acute coronary syndromes. The PURSUIT Trial Investigators. Platelet Glycoprotein Ib/IIla in Unstable Angina; Receptor Suppression Using Integrilin Therapy, N Engl J Med 1998;339:436- 43,

20. PRISM Investigators, A comparision of Aspirin plus tirofiban with aspirin plus heparin for unstable angina. Platelet Receptor Inhibition in Ischemic Syndrome Management(PRISM) study investigators. N Engl J Med 1998;338: 1498-1505

21. PRISM-PLUS Investigators. Inhibition of the platelet glycoprotein IIb/IIla receptor with tirofiban in unstable angina and non Q-wave myocardial infarction. Platelet Receptor Inhibition in Ischemic syndrome management in patients Limited by Unstable Signs and Symptoms(PRISM-PLUS) study investigators. N Engl J Med 1998;338; 14481497 
22. PARAGON Investigators, International randomized controlled trial of lamifiban (a platelet glycoprotein IIb/IIla Inhibitor), heparin, or both in unstable angina. Platelet Ilb/llla antagonism for the Reduction of Acute coronary syndrome events in a Global Organization network, Circulation 1998.97; 2386-2395

23. Global Organization Network (PARAGON B) Investigators. Randomized, placebo controlled trial of titrated intravenous lamifiban for acute coronary syndrome. Circulation 2002;105;316-321

24. Simoons MI: GUSTO IV ACS Investigators. Effect of glycoprotein IIb/Illa receptor blocker abciximab on outcome in patients with acute coronary syndromes without early coronary revascularization; the GUSTO IV ACS randomized trial, Lancet 2001; 357; 1915- 1924

25. Antnan EM, Glugliano RP, Gibson CM, Mccabe CH, Coussement P, Kleiman NS, et il, Abciximab fascilates the rate and extent of thrombolytic results of the thrombolysis in Myocardial Infarction (TIMI) 14 trial, Circulation 1999;99:2720-2732

26. SPEED investigators. Trial of Abciximab with and without low dose reteplase for acute myocardial infarction, Strategies for Patency enhancement in the Emergency Department(SPEED) group. Circulation 2000; 101; 2788-2794.

27. Brener SJ, Acynier U, Adgey AA, Vrobel TR, Ellis SG, Neuhaus KL, et al. ebtifibatide and low dose tissue plasminogen activator in acute myocardial infarction; the integrilin and low dose thrombolysis in acute myocardial infarction(INTRO-AMI) trial, J AM Coll Cardiol 2002;39; $377=386$

28. Glugliing RP, Roe MT, Harrington RA $\leq$ Gibson CM, Zeymer U, Van de Werf F, et al. INTEGRITI Investigators. Combination repercussion therapy with ebtifibatide and reduced dose tenecteplase for ST elevation myocardial infarction; results of the integrili and lenecteplase in acute myocardial infarcion (iNTEGRITI phase II angiographic trial, JAM Coll Cardiol 2003; 41;125 1-126 
29. Antmain EM, Louwerenburg HF, Baars HP, Wesdrop JC, Hamer B, Bassand JP, et al. Enoxuparin as adjunctive antithrombin therapy for ST elevation myocardial infarction; results of the ENTIRE thrombolysis in myocardial infarction (TIMI) 23 trial, Circulation 2002; 105: 1642-1649

30. Ohman EM, van de Werf F, Antaman EM, Califf RM, de Lemos JA, Gibson CM, et al. FASTER (TIMI 24) Investigators. Tenecteplase and tirofiban in ST segment elevation acute myocardial infarction; results of a randomized trial, Am Heart J 2005; 150 : 79-88

31. Topol EJ GUSTO V Investigators, Reperfusion therapy for acute myocardial infarction with fibrinolytic therapy or combination reduced fibrinolytic therapy and platelet glycoprotein IIb/IIla inhibition ; the GUSTO $¥$ randomized trial. Lancet 2001;357: 1905-1914

32. ASSENT-3 Investigators, Efficacy and safety of tenecteplase in combination with enoxaparin, abeiximab, or unfractionated heparin; the assent\# randomized trial in acute myocardial infarction, Lancet 2001; 358:605-613

33. Kereiakes DJ, Lincoff AM, Anderson KM, Achenbach R, Patel KR, Barnathan E, et al. EPIC investigators: EPILOG Investigators: EPISTENT Investigators. Abciximab survival advantage following percutaneous intervention is predicted by clinical risk profile. AmJ Cardiol 2002; 90:628-630

34. Cura FA, Bhatta DL, Lincoff AM, Kapadia SR, L' Allier PL, Ziada KM, et al. Pronounced benefit of coronary stenting and adjunctive platelet glycoprotein Ilb/IIla inhibition in complex atherosclerotic lesions, Circulation 2000; 102:28-34

35. Guidelines for percutaneous coronary intervention, The Task force for percutaneous coronary interventions for Europian society of cardiology, 2005,

36. Mario SP, Lincoff AM, Ellis SG, Bhatt DL<Tanguay JF, Kleiman NS, Hammoud T, Booth JE, Sapp SK, Topol EJ, Optimizing the percutaneous interventional outcomes for patients with diabetes mellitus: result of the EPISTENT( Evaluation of platelet 
Ilb/ Illa inhibitor for stenting trial) diabetic substudy, Circulation 1999; 100: 2477: 2484

37. Roffi M, Chew DP, Mukherjee D, Bhatt DL, White JA, Heeschen C, et al. Platelet glycoprotein Ilb/Illa inhibitors reduce mortality in diabetic patients with non-ST segment elevation acute coronary syndromes. Circulation 2001; 104:2767-2761 